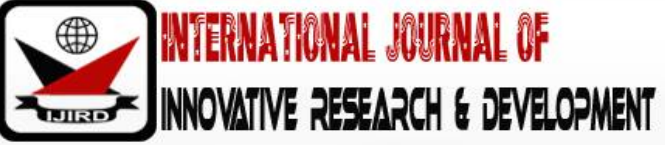

ISSN 2278 - 0211 (Online)

\section{Study for Assessing Effluents Quality for Factories in Khartoum North- Sudan}

\author{
Igbal Mohamed Abdul Raheim Suliman \\ Manager, Department of Buildings Raw Materials \\ Building Materials \& Refractories Research Institute, \\ Industrial Research \& Consultancy Center
}

\begin{abstract}
:
The current study was carried out in three factories namely; Bittar Oil and Soap, Tital factory and Ridda factory which they were present in Industrial area of Khartoum North, Sudan to evaluate the pollution in these factories. The samples were collected from the last manhole of discharge waste to the common sewer through aseptic tank. Parameters used according to the industrial waste water local order 1971 to determine the limits of oil and grease, temperature and $\mathrm{pH}$. The liquid wastes sampled \& analyzed for their chemical characteristic in accordance with Standard Methods (American Public Health Association, American Water Works Association \& Water Pollution Control Federation, 1989). The physical characteristics were determined after temperature was measured immediately at sampling time; using a mercury thermometer in degrees centigrade and the $\mathrm{pH}$ value by electric $\mathrm{pH}$-meter \& conductivity by conductivitymeter, odor and color by (Human sense). The results obtained showed that the three factories in Khartoum North Industrial area have an adverse impact on the sewer system.

In order to minimize or prevent or control the health hazards resulting from their effects, the study has recommended more practical, efficient and economical control methods and measures or technological treatment facilities and these are:

1-Enforcement of criteria, standards, legislations and laws special for the protection of the environment or the work environment.

2-Coupling of oil recovery tanks with septic tanks in the pretreatment. The effluent can be discharged into public sewers or used as irrigation.
\end{abstract}

Keyw ords: Oil and grease, temperature, wastewater, and $\mathrm{pH}$

\section{Introduction}

Treatment means removing impurities from water being treated; and some methods of treatment are applicable to both water and wastewater. The physical infrastructure used for wastewater treatment is called a "wastewater treatment plant" (WWTP) [1] By-products from wastewater treatment plants, such as screenings, grit and sewage sludge may also be treated in a wastewater treatment plant [2] If the wastewater is predominantly from municipal sources (households and small industries) it is called sewage and its treatment is called sewage treatment.

Industrial wastewater from soap and oil industries represents a heavy pollution source on their receiving water body and industrial wastewater effluent was discharged via gravity sewers to the public sewerage system. To control soap and oil factory sewer to allowable limits the following consideration must be done. Started with the open circuit cooling systems converted to closed circuit is essential to reducing the quantity of the discharged wastewater. The heavily polluted oil and grease (O\&G) wastewater from the refinery unit must treated via two gravity oil separator (GOS) units, dissolved air floatation (DAF) and biological units in order to reduce the high levels of O\&G, BOD, COD, and SS to the allowable limits. The heavily polluted waste effluent from the 'red water' saponification unit must be treated separately by acidification to convert the emulsified fatty acid to free form in order to be separated through an oil separation unit. The effluent must then be passed to liming stage to neutralize excess acidity and precipitate some of the dissolved matters. The mixture finally clarified and the $\mathrm{pH}$ must adjust to the allowable limits. The effluent wastewater from the above processes is collected and mixed in a final equalization tank for discharging effluent to the public sewerage system. The characteristics of the effluent water are very good with respect to the allowable limits for discharging effluent to the public sewerage system [3].

Grease and oil may be recovered for fuel or saponification. The heavily polluted waste effluent from the 'red water' saponification unit must be treated separately by acidification to convert the emulsified fatty acid to free form in order to be separated through an oil separation unit. The effluent must then be passed to liming stage to neutralize excess acidity and precipitate some of the dissolved matters. The mixture finally clarified and the pH must adjust to the allowable 
effluent to the public sewerage system. The characteristics of the effluent water are very good with respect to the allowable limits for discharging effluent to the public sewerage system [3].

Reused as reclaimed water: For municipal wastewater the use of septic tanks and other On-Site Sewage Facilities (OSSF) is widespread in some rural areas, for example serving up to 20 percent of the homes in the U.S [4]. One type of aerobic treatment system is the activated sludge process, based on the maintenance and recirculation of a complex biomass composed of micro-organisms able to absorb and adsorb the organic matter carried in the wastewater. Anaerobic wastewater treatment processes (UASB, EGSB) are also widely applied in the treatment of industrial wastewaters and biological sludge. Some wastewater may be highly treated and reused as reclaimed water. Constructed wetlands are also being used. Treatment orders: There are many orders around the world to govern water pollutions in Urobe the Council Directive 91/ 271/ EEC on Urban Wastewater Treatment was adopted on 21 May 1991, (UCD (91/91/271/ EEC), 1991)) [5] amended by the Commission Directive 98/15/EC (UCD (98/15/ EC), 1991)) [6]. Commission Decision 93/ 481/ EEC defines the information that Member States should provide the Commission on the state of implementation of the Directive [7]. In American the Clean Water Act is the primary federal law in the United States governing water pollution [8]. And in Sudan order 1971 for sewer waste was published and ordered [9].

\section{Materials and Methods}

2.1. Location

The three factories namely; Bittar Oil and Soap, Tital factory and Ridda factory were present in Industrial area of Khartoum North, Sudan.

\subsection{Sample sources}

The sources of samples for the three factories; Bittar Oil and Soap, Tital factory and Ridda factory were collected

from:

\subsubsection{Bittar Oil and Soap Factory Sample}

Samples of wastewater were collected from the selected plants, from the last manhole. Waste water discharged to the common sewer through aseptic tank.

\subsubsection{Tital Factory Sample}

Waste water discharged to the common sewer through aseptic tank.

\subsubsection{Ridda Factory Sample}

Waste water discharged to sedimentation system and then common sewer through aseptic tank.

\subsection{Parameters Used}

Parameters used according to the industrial waste water local order 1971 [9] is oil and grease, temperature and $\mathrm{pH}$.

\subsection{Liquid Waste Analysis}

The liquid wastes sampled \& analyzed for their chemical characteristic in accordance with Standard Methods [10].

\subsubsection{Physical Examination of Liquid Waste}

The physical characteristics were determined after [11]. Temperature was measured immediately at sampling time; using a mercury thermometer in degrees centigrade, \& the $\mathrm{pH}$ value by electric $\mathrm{pH}$-meter \& conductivity by conductivity-meter, odour and colour by (Human sense). The method (G5-40) was used for oil and grease [12].

\subsubsection{Liquid Waste Investigation}

The amount of liquid waste was calculated from the daily waste disposal. Field trips and visits to dumping areas were carried out in addition to the available records or estimates from the concerned departments. The waste disposal labourers, were also interviewed, to know the amount of waste disposed

\subsection{Comparison Standard Method for Comparison}

A standard method limits for the examination minimum and maximum limits of water and wastewater is Sudanese Order 1971 [9].

\subsection{Statistical Analysis}

Statistical package for social sciences (SPSS) software was used for the analysis. Analyses of variance, followed by Duncan multiple range test with significance level $\mathrm{p} \leq 0.05$ were performed on the data [13]. 


\section{Results and Discussion}

\section{1. $\mathrm{pH}$ range $(\mathrm{mg} / \mathrm{L})$ in Three Factories}

The results of $\mathrm{pH}(\mathrm{mg} / \mathrm{L})$ in the three factories; Bittar Oil and Soap, Tital factory and Ridda factory were illustrated in table (1). The minimum ranges of $\mathrm{pH}$ obtained from the three factories; Ridda factory, Bittar Oil and soap and Tital factory were (7.2), (6.7) and (4.4) $\mathrm{mg} / \mathrm{L}$ respectively; with no significant difference between Tital factory and Ridda factory, while there was a significant difference between Tital factory and Bittar Oil andsoap. The Maximum ranges of $\mathrm{pH}$ obtained from the three factories; Ridda factory, Tital factory and Bittar Oil and soap and were (08.90), (08.50) and (05.80) $\mathrm{mg} / \mathrm{L}$ respectively. There is no significant difference between Ridda and Tital factories, while there was a significant difference between Ridda factory and Bittar Oil and soap factory. The $\mathrm{pH}$ results were found to be between $4.4 \mathrm{mg} / \mathrm{L}$ to $8.9 \mathrm{mg} / \mathrm{L}$, where as the limits to public sewers are $5.5 \mathrm{mg} / \mathrm{L}$ to $10 \mathrm{mg} / \mathrm{L}$. The local values were below local standard pH 5.5mg/ L. In Such cases neutralization tanks can be used to control the pH range (Sudan Order, 1971).

\begin{tabular}{|c|c|c|}
\hline \multirow{2}{*}{ Factory } & \multicolumn{2}{|c|}{ pH rangee (mg/ L) } \\
\cline { 2 - 3 } & Min. & Max. \\
\hline Bittar Oil and Soap & 4.4 & 5.8 \\
\hline Tital factory & 6.7 & 8.5 \\
\hline Ridda factory & 7.20 & 8.9 \\
\hline Mean & 6.1 & 7.73 \\
\hline Standard Deviation & 1.5 & 1.69 \\
\hline
\end{tabular}

Table 1: pH Range (mg/ L)

\subsection{Temperature ${ }^{0} \mathrm{C}$ in Three Factories}

Table (2) showed the results of Temperature ${ }^{\circ} \mathrm{C}(\mathrm{mg} / \mathrm{L})$ in the three factories; Bittar Oil and Soap, Tital factory and Ridda factory. The minimum ranges of Temperature ${ }^{0}$ Cobtained from the three factories; Tital factory, Bittar Oil / soap and Ridda factory, were (50.00), (47.00) and (40.00) respectively; with a significant difference in maximum range was obtained between the three factories. The Maximum ranges of Temperature ${ }^{\circ} \mathrm{C}$ obtained from the three factories; Bittar Oil I soap factory. Tital factory and Ridda factory were (58.00), (57.00) and (50.00) respectively. no significant difference between Tital factory and Ridda factory, while there was a significant difference between Tital factory and Bittar Oil / soap. The entire waste water effluent temperature obtained from the factories were between 40 - $58 \mathrm{C}$, which are less than 60 C the maximum limit (Sudan Order, 1971).

\begin{tabular}{|c|c|c|}
\hline \multirow{2}{*}{ Factory } & \multicolumn{2}{|c|}{ Temperature ${ }^{\mathbf{O}} \mathbf{C}$} \\
\cline { 2 - 3 } & Min. & Max. $^{\text {Max }}$ \\
\hline Bittar Oil and Soap & $47.00^{\mathrm{a}}$ & $58.00^{\mathrm{a}}$ \\
\hline Tital factory & $50.00^{\mathrm{a}}$ & $57.00^{\mathrm{a}}$ \\
\hline Ridda factory & $40.00^{\mathrm{a}}$ & $50.00^{\mathrm{a}}$ \\
\hline Mean & 45.67 & 55.00 \\
\hline Standard Deviation & 05.13 & 04.36 \\
\hline
\end{tabular}

Table 2: Temperature ${ }^{0} \mathrm{C}$

\subsection{Oil and Grease Range (Mg/ L) in Three Factories}

The results of Oil ad grease range (mg/ L) in the three factories; Bittar Oil and Soap, Tital factory and Ridda factory were illustrated in table (3). The minimum ranges of Oil and grease range obtained from the three factories; Ridda factory, Tital factory, and Bittar Oil and soap factory were 2450, 2450 and 230 (mg/ L) respectively; with no significant difference in maximum range was obtained between Ridda factory and Tital factory but there is a significant difference with Bittar Oil and soap factory. The Maximum ranges of Oil and grease range obtained from the three factories; Tital factory, Ridda factory and Bittar Oil and soap were (4867.0), (430.00) and (250.00) mg/ l respectively. A significant difference between Tital factory and Ridda factory, while there was no significant difference between Ridda and Bittar Oil and soap factories. All the levels of oil and grease in the factories were highest than the standard but Tital factory $2000 \mathrm{mg} / \mathrm{L}$ increase than the others. These values must be below $150 \mathrm{mg} / \mathrm{L}$ as local standard requirement (Sudan Order, 1971).

\begin{tabular}{|c|c|c|}
\hline \multirow{2}{*}{ Factory } & \multicolumn{3}{|c|}{ Oil and Grease Range (mg/ L) } \\
\cline { 2 - 3 } & Min. & Max. \\
\hline Bittar Oil and Soap factory & $0230.00^{\mathrm{b}}$ & $0250.00^{\mathrm{b}}$ \\
\hline Tital factory & $2450.00^{\mathrm{a}}$ & $4867.00^{\mathrm{a}}$ \\
\hline Ridda factory & $2450.00^{\mathrm{a}}$ & $0430.00^{\mathrm{b}}$ \\
\hline Mean & 0993.33 & 1849.00 \\
\hline Standard Deviation & 1262.00 & 2615.21 \\
\hline
\end{tabular}

Table 3: Oil and Grease Range (mg/ L) 


\section{Conclusion}

From the above we can come to conclude that:

- Khartoum North Industrial area is relatively polluted with waste water.

- Lower mhjyulimit of Sudanese factories pH is below the recommended level of public sewers. In such cases neutralization tanks can be used to control the $\mathrm{pH}$ range and discharged large quantities of effluents with high $\mathrm{pH}$ value and very nasty odor.

- Entire waste water effluent temperature obtained from the factories less than the maximum recommended level of public sewers.

- All the levels of oil and grease in the factories were highest than the local standard requirement.

\section{Recommendations}

- All the factories especially Tital oil, soaps and grease must be below the $150 \mathrm{mg} / \mathrm{L}$ as local standard requirement by recovery of fatty materials from soap stock, animal food or pretreatment before dispose ding them I the main sewer.

- In general, proper plant sanitation and favorable working conditions should be maintained.

- Industrial and occupational accidents control measures showed are applied.

- Production manager should be trained and educated to become environmental conscious and to enable them to establish a proper stiffing and structural organization.

- Industrial liquid waste showed recycled, suitable materials be recovered and reused.

- Waste showed is minimized using high technology that gives minimum amount of waste with minimum costs.

- Local order of 1971 should be implemented. And industrial building act 1971 should be activated.

- All the plants should carry out environmental audits.

- New license for oil manufacturing with soap stock making order must be issued and enforced.

- Establishment of local waste quality disposal standard, for the various types of wastes and enforcement of these legislation and standards. Other local orders for clean production should be issued an enforced.

- Cooperation between municipal authorities and state and the factories administration is required to solve the problem of waste water.

- Develop the awareness of waste handlers regarding the affects of industrial wastes on health and environment through health education.

- Site allotted by municipal authorities for disposing of waste water should be allocated based on scientific knowledge to avoid polluting the environment.

\section{References}

i. Hammer, Mark J. (1975). Water and Waste-Water Technology. New York: John Wiley \& Sons. pp.300-302.

ii. Metcalf and Eddy (2003) Wastewater engineering: treatment and reuse (4th ed.), Inc., McGraw Hill, USA., p. 1220 and 1138. (Metcalf and Eddy, 2003).

iii. Abdel-Gawad, S. and Abdel-Shafy, M.( 2002). Pollution control of industrial wastewater from soap and oil industries: a case study. Water, 46(4-5):77-82.

iv. U.S.E.P.A. (2008)."Septic Systems Fact Sheet."U.S. Environmental Protection Agency, Washington, D.CEPA publication no. 832-F-08-057.

v. $\operatorname{UCD}(91 / 91 / 271 / \mathrm{EEC})(1991)$.

vi. $\quad \operatorname{UCD}(98 / 15 /$ EC) (1991). "EUR-Lex - 31998L0015 - EN - EUR-Lex".

vii. $\quad$ UCD (93/ 481/ EEC) (1991). "EUR-Lex - 31993D0481 - EN - EUR-Lex".

viii. ACWA (1972).Clean Water Act.33 U.S.C. § 1251et seq. Pub.L. 92-500, United States.

ix. $\quad$ Sudan Sewer Waste Order, 1971

x. American Public Health Association, American Water Works Association \& Water Pollution Control Federation, 1989.

xi. Clesceri, L. S., Greenberg, A. E., Trussell, R. R., American Public Health Association., American Water Works Association \& Water Pollution Control Federation. (1989). Standard methods for the examination of water and wastewater. Washington, DC: American Public Heqalth Association.

xii. Link, 1997

xiii. Duncan's, Multiple Range Test (MRT)

xiv. [14].Gomez, K. A. and Gomez, A. A. (1984). Statistical Procedures for Agricultural Research. 2nd edition. pp. 8-20. Johon Wiley and Sons, Inc. New York, USA 